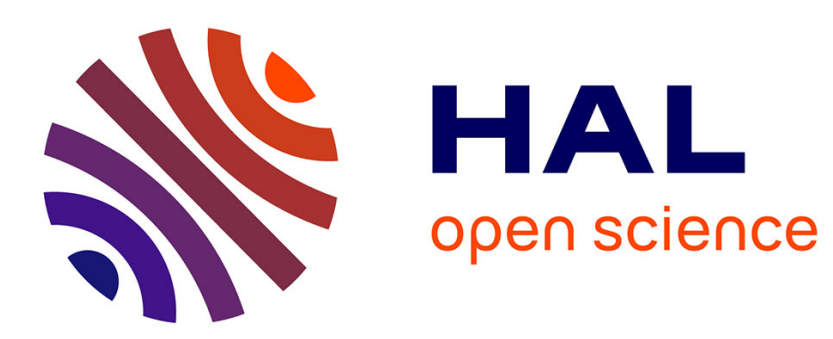

\title{
Negotiating the Pitch: For a Diplomatic History of A, at the Crossroads of Politics, Music, Science and Industry Fanny Gribenski
}

\section{To cite this version:}

Fanny Gribenski. Negotiating the Pitch: For a Diplomatic History of A, at the Crossroads of Politics, Music, Science and Industry. Understanding Musical Diplomacies. Sounds and Voices on the International Stage, 2018. hal-03005013

\section{HAL Id: hal-03005013 \\ https://hal.science/hal-03005013}

Submitted on 13 Nov 2020

HAL is a multi-disciplinary open access archive for the deposit and dissemination of scientific research documents, whether they are published or not. The documents may come from teaching and research institutions in France or abroad, or from public or private research centers.
L'archive ouverte pluridisciplinaire HAL, est destinée au dépôt et à la diffusion de documents scientifiques de niveau recherche, publiés ou non, émanant des établissements d'enseignement et de recherche français ou étrangers, des laboratoires publics ou privés. 


\section{Chapter Eight}

\section{Negotiating the Pitch: For a Diplomatic History of $A$, at the Crossroads of Politics, Music, Science and Industry}

\section{Fanny Gribenski}

On June 30, 1971, the Committee of Ministers of the European Union adopted a Resolution "on the standardization of the initial tuning frequency." The text recommends the government of Member states to "introduce in their national territories [...] the international note [...] Treble A" graphically represented on the second lower staff of a musical stave bearing a Gclef and "defined as a note whose frequency is $440 \mathrm{~Hz}$." An appendix listing a number of "arrangements" and technical recommendations aimed at helping to enforce this resolution ends with the following, "The assistance of the ISO (International Organization for Standardization) would be of great help in the application of the resolution." Presented as a simple tool to enforce the EU's musical politics, the international organization was actually responsible for a similar resolution issued in 1953, that served as draft for the ISO 16 norm, entitled "Standard tuning frequency," published in 1975. Both ISO texts confirmed an initial agreement reached in London in 1939 under the auspices of the International Federation of Standardizing Agencies.

For most of the history of music, pitches were fluctuating concepts - as pointed out by Rousseau in his Music Dictionary where he wrote, that "perhaps since music exists, one has never concerted in the same tone." Countries, cities and individual musical institutions used to perform music according to their own tones. In the modern era, the organ in churches was the prime instrument of tuning, which pitches were fabricated to accord to the vocal range of choir singers' voices. Pitch standardization constituted a response to complaints from music theorists, musicians, and instrument builders about both the lack of uniformity in musical practices and the constant urge during the nineteenth century to raise the frequency of performing pitches in order to create ever-brighter sound effects. The assignment of a stable and world-recognized frequency to pitches is the result of international negotiations at the crossroads of music, science and industry throughout the nineteenth and the first half of the twentieth century that involved a remarkably dynamic field of actors. Yet performers were the ones to raise the initial cry for a musical standardization, it is mostly composers, scientists, instrument makers and state representatives who actually led the negotiations. These different groups were not stable over the course of history and we will see that telling the "story of A" involves tracking the gradual empowerment of new actors and forces aiming to literally tune the world.

Although the history of shifting reference pitches over the course of the last four centuries has been thoroughly documented from the perspective of performance practice, ${ }^{2}$ it has remained underexplored as a social, political and historical process in its own right. Science historian Myles Jackson has however paved the way for such approaches in a chapter of his book dedicated to the relationship between musicians, scientists and instrument makers in nineteenth century German territories. ${ }^{3}$ The present chapter aims to develop new directions for investigations in further territories and time periods in order to highlight the invention of the current musical standard ruling musical practices in the Western world. Why is $A$ tuned to 440 hertz our global standard pitch? What were the diplomatic procedures that led to this adoption? Who were the actors involved in negotiations? Answers to such question will demonstrate the political, technological, scientific and aesthetic contingencies underlying the historical construction of one of the seemingly most "natural" and stable objects of 
contemporary musical performance, itself the result of a cacophony of competing views and interests.

Following the country's national standardization of the musical pitch, France's voice prevailed in the first phase of international negotiations. After World War I however, France lost its authority in the concert of nations where the lead was taken over by the United States. But the empowerment of the New World actually resulted in a crucial shift in the diplomatic history of pitch: in the interwar period, the spread of the American standard followed new procedures, involving new actors who were no longer directly related to the administrative powers of states. The "French pitch" that ruled the Western world from 1859 was tuned to 435 hertz, only five frequencies lower than the new standard adopted in London in 1939: a barely audible difference. But in this chapter, I argue that the almost negligible increase of the Western standard note actually revealed the spectacular empowerment of new actors and forces in the history of "sound diplomacy."4

The diplomatic history of A therefore offers a good example of the way local and global musical scenes relate to each other. Actors leading negotiations on a regional or national scale especially tend to lose their authority on a global level, on which commercial interests appear to be the primary forces driving the construction of international musical norms. Whereas figures in charge of cultural diplomacy appear unable to secure the interests they represent, private actors and industry impose themselves as the agents of a universal harmony.

\section{$A 435$ or the Leading Voice of France in Pitch Negotiations}

Pitch standard had long constituted an issue of concern for music theorists and acousticiansstarting with Praetorius and continuing with Mersenne, Sauveur, Bedos de Celles and Chladni-when the first practical attempts to fix it were made in the nineteenth century, addressing issues in musical performance. In the first decades of the century, musicians and observers of the European musical life would first complain about the lack of uniformity in pitches across space that made it hard for performers to play in various places, at a time when musical tours were multiplying. In the columns of the Allgemeine musikalische Zeitung, for instance, one finds multiple examples of claims in favor of the adoption of a European standard pitch presented as a means to ease musicians' travels. ${ }^{5}$ But performers, composers and critics would also point out the sharpening of pitches over time, which they attributed to the development of instrumental music as well as to the increasing presence of brass instruments in orchestras. ${ }^{6}$ Whatever various causes they would invoke, they claimed this rise in frequency put singers in a difficult situation since the canonization of old and classical repertories involved the persistence of vocal works by Mozart, Gluck, Haendel and other masters on European stages written for sometimes much lower performing pitches. ${ }^{7}$

In France, a country marked by early centralization of state power, attempts to stop this process were made at the Royal Academy and the Conservatory starting as early as around 1800. ${ }^{8}$ In 1824, following the complaints of the institution's prima donna $\mathrm{M}^{\mathrm{me}}$ Branchu, the minister of the King's house decided to appoint a commission in order to fix a lower diapason pitch at the Paris opera. ${ }^{9}$ The committee suggested by Habeneck, the Opera director, and approved by the government, comprised musicians in charge of the main French musical institutions of the time, including the orchestra conductors of the Opera and the Théatre-Italien, as well as heads of the Royal Chapel and the Conservatory. ${ }^{10}$ During the meeting of the commission, the Opera flutist and oboist were asked to play their $A$ s and the latter were compared with older instruments pitches as well as with diapason forks used at various times in different French institutions. Members of the commission then decided, by 
listening and comparing these pitches, to lower the Opéra diapason by approximately threeeighths of a tone. Since they feared that, "in the first days of its adoption, this improvement might surprise the audience by disaccustoming them to the brighter effects to which their ears have become habituated over the past few years", they recommended that "the diapason of the Royal Academy [...] [became] at the same time the diapason of the lyrical theaters, the Royal School and the Chapel.",11

This was not the last time the French state would mingle with sound issues. During the Second Empire, it drove a national standardization of the performing pitch, as it had previously standardized the metric system, based on new scientific procedures that emphasized precision as a value unto itself. This time, the call for standardization didn't come from performers, but from the scientific world. In 1855, at the time of the second world fair, Jules-Antoine Lissajous, a young $\mathrm{PhD}$ in physics, ${ }^{12}$ called for the organization of an international congress that would be in charge of stabilizing and unifying pitches all over the world. ${ }^{13}$ In order to build support among French elites in industry and science, Lissajous made his call in front of the members of the prestigious Society for the Encouragement of National Industry (Société d'encouragement pour l'industrie nationale) located in fancy Saint-Germain des Prés in Paris, an association created by Napoleon in 1801 to encourage innovation by gathering scientists, engineers, and bankers. ${ }^{14}$ During the Second Empire, the Society served as the unofficial office for patents validation. In front of his bright audience, Lissajous argued that the art of singing was in great danger because of an exponential raise of the diapason pitch of approximately one and a half tone since the reign of Louis XIV, which he had his listeners experience by making sound seven different diapason forks from different time periods. ${ }^{15} \mathrm{He}$ also exposed the great advantages the adoption of a universal standard pitch would have for the flourishing business of musical instruments' making in Second Empire France. With this talk, Lissajous was also clearly helping his own agenda by designating himself as the future designer of appropriate tools meant to guarantee and enforce this standardization process ${ }^{16}$ - which he indeed ended up doing.

The first to heed Lissajous' call were instrument makers, who gathered under the authority of the piano builder's union in $1856 .{ }^{17}$ Two years later responding to the pressures of the builders, the French ministry of State appointed a commission ${ }^{18}$ charged with solving the artistic and commercial difficulties raised by the increase and the lack of uniformity of the musical pitch. ${ }^{19}$ This new diapason committee was very different from the 1824 Opera committee. Besides six composers, most of them members of the Institute, it comprised four representatives of the French state (Pelletier, Doucet, Mellinet and Monnais) and two scientists (Lissajous and Despretz). ${ }^{20}$ The ambition of the committee was no less than producing a rational norm that would apply to the rest of the world: "Isn't it desirable, the members of the committee asked in their report, that a uniform and now fixed diapason adds to this intelligent community a supreme link and that an $A$, always the same, resonating on the whole surface of the universe with the same vibrations, eases the musical relationships and makes them even more harmonious?"21 This scientific and Universalist ambition was clearly manifested by the procedures of the commission, which based its study on a broad spectrum of diapason forks from all over the western world. Taking its distance with the approximate methods of the 1824 Opera Commission, finally, the committee used a precise instrument, the "siren" invented by physicist and member of the Academy of Sciences Cagniard de la Tour to measure the different diapasons. ${ }^{22}$

If instrument builders had played a decisive role in catching the attention of the government, their role was minimal in the negotiations. In its report, the committee even accused them of having raised the pitch to create brighter sounds. Although the standard was presented as a compromise ${ }^{23}$ between the original diapason of old masterpieces and the sharper tones used especially by military bands, it represented a significant decrease of the 
pitch that imposed the authority of composer to makers-whose ear, the commission claimed in a very Rousseau-esque fashion, was tuned to the laws of nature, embodied by the human voice - and the preeminence of vocal genres on instrumental music, accordingly to the hierarchies ruling the French musical scene. An arrêté was issued on February 16, 1859 that fixed a diapason normal at 435 hertz $^{24}$ that had to be adopted by "all musical institutions [...] authorized by the State." 25 In the same way a standard meter had been settled in the legislative chamber in 1799 as a reference after the revolutionary standardization of the metric system, ${ }^{26}$ a model of the diapason normal was stored at the Conservatory where a bell tuned to $A 435$ hertz was also installed to accustom student's and professors' ears to this new pitch. ${ }^{27}$ In order to enforce this law outside of the Conservatory, Lissajous was charged to control and validate every new diapason fork that was to be produced. ${ }^{28}$ Archival material however reveals that this was not sufficient, and as in the case of the metric system, the standardization of A actually somehow increased the diversity of pitches by creating a parallel market of instruments tuned to $A 435$ hertz but that did not make other performing pitches disappear. ${ }^{29}$

The French pitch nevertheless served as the first standard across the world. Over the next two decades, individual countries, cities and institutions began to adopt the French pitch. Vienna immediately introduced it and in 1879 it became the official standard of Spain. ${ }^{30}$ Several German cities also adopted the new French standard, as did many American institutions. ${ }^{31}$ In 1885, pitch joined the cohort of industrial issues addressed by the "conference system" described by Craig N. Murphy as the diplomatic standard in late nineteenth century Europe, linked with the rise of civil experts in a growing range of fields. ${ }^{32}$ The Austrian government appointed an international committee in charge of fixing a common European standard pitch, addressing the pressures of the Gesellschaft für Musikfreunde. Responding to the invitation of the Austrian State, delegates from Italy, Hungary, Sweden, Russia and three German states gathered in Vienna on November 16-19. ${ }^{33}$ As in the case of conference dedicated to the standardization of other objects, negotiations are led by actors who are not primarily in charge of international relations.

By the time the conference began, Austria had already chosen the French pitch as its national standard, arguing that the broad diffusion of this reference made it the most relevant as an international standard. ${ }^{34}$ During the conference, the practical considerations of Austrian experts were opposed by the Italian delegation, which suggested the adoption of $A 432$, claiming that a standard pitch had to be based on mathematical principles. Following the argument made by physicist Charles Meerens in $1876^{35}$ Italian representatives claimed it was a far more consistent reference than the French pitch, as it would generate non-decimal frequency numbers for all the tones of the scale. At a time when "the rays of the sun of science heat[ed] and pierce[d] all disciplines of human knowledge as well as of the arts," choosing 435 hertz instead of the scientific standard would be "sort of an anachronism." ${ }^{, 36}$ But the other delegates argued that the most practical choice was the French pitch as it was already spread out in Europe.

At the end of the nineteenth century, a first international agreement on musical pitch had been reached. With its standard, the French government would reinforce the centralization of its musical model structured by the pyramidal education system of the Conservatoire and local succursales, and the authority of the Academy of Fine Arts filled with composers who illustrated themselves in the very political genre of opera. With its norm, the French state would also secure its scientific- and musical-instrument makers a unified space for national and international trade and furthermore impose itself as the main arbiter on Europe's musical scene by synthesizing and balancing all its aesthetical and social components. The French pitch encapsulated the entire and complex musical world of its time, by reconciling old and new; vocal and instrumental; civil and military musical traditions. 
As in the case of other standards, science and commerce played a crucial role along with the state. ${ }^{37}$ The French pitch traveled thanks to international exchanges of measures and musical instruments and these early conquests were key to later international negotiations. In Vienna, mathematical considerations were defeated by the reality of the presence of the French pitch all the way to the margins of Europe. The history of $A 435$ nevertheless also reveals an important number of resistances, both on a national and international scale. To begin with, the state did not provide departmental musical institutions with the financial means to enforce standardization. Furthermore, major countries were absent of the negotiation table in Vienna, including the United States who played an important role in redefining the new frequency. More than a reconfiguration of the concert of nations, however, the history of pitch standardization after World War I reveals the failure of state-diplomacy in regulating international musical relations. The construction of a unified globalized musical scene, we shall see, was dependent upon the rise of a new model of governance dominated by international organizations representing the interest of the musical industry that overcame states' pretentions to rule the international musical stage. Contradicting the narrative of musical internationalism's failure in interwar, the success story of $A 440$ opens new avenues for the history of musical diplomacy by bringing sound to the fore.

\section{A 440: The Brighter Sound of Industrial Internationalism}

In a 1900 article dedicated to the history of the musical pitch in the United States, physicist Charles R. Cross concluded that "the International pitch chosen in Vienna has come to be generally adopted, so that it is now the standard of this country," explaining that "the different manufacturers and musical organizations necessarily followed the usage abroad, and the same gradual rise in pitch that occurred there occurred here also." ${ }^{38}$ In 1917, however, the American Federation of Musicians, a union created in 1896, voted for the adoption of a higher frequency of $A 440$ hertz. This decision resulted from the active campaign of a percussion instrument maker called John Calhoun Deagan who was familiar with the work of Hermann von Helmholtz and introduced German instruments to America. ${ }^{39}$ The reasons of Degan's commitment to $A 440$ still need to be elucidated, but there were obvious advantages in this shift. Retuning the pitch would not only secure American builders a dominant position in the large domestic market by protecting them from transatlantic imports, but given the size of the US market, America's voice would also be positioned to impose itself on the international stage. In 1916, Deagan patented a tuning instrument called the "Dea-Gan-Ometer." In the prospectus he published to describe his invention, emphasizing the confusion of pitches across the Western world, he claimed that his instrument would solve the issue of standard pitch $^{40}$ - revealing his Universalist commercial ambitions.

In the years following the American Federation's decision, debates arose about this choice that involved important financial efforts, especially after The Sun published an article asking why the union had chosen the "German pitch"-since $A 440$ had been adopted during a conference of natural scientists held in Stuttgart in $1834,{ }^{41}$ which could well be the cause of Deagan's adhesion to this standard, interested as he was in the work of German acousticians and builders. "Why," asked the reporter of the New York Sun, "was the German pitch selected," only a few weeks after America had declared war to Germany? This episode is rather ironic given the patriot and anti-German feelings cultivated by the Federation at the time of its decision ${ }^{42}$ and there is little to be argued about the association's implicit support to Germany. Despite the awkward resonances of the new American standard and the controversies it created in the 1920s, in 1925, the American Music Industries Chamber of 
Commerce confirmed the decision of the Federation of Musicians. At this point, $A 440$ was definitely perceived as American, and European countries and actors started reacting to the shifting sounds coming from the New World.

In the vein of Deagan's Universalist claims and aims to impose his standard on the rest of the Western world, a number of American instrument makers led campaigns in favor of the adoption of the American pitch in Europe. Gathering concerns about this issue, the International Commission for Intellectual Cooperation of the League of Nations inscribed the issue of pitch on its program in $1926 .{ }^{43}$ After two years of work, the Commission declared itself in favor of the Vienna standard, a way of re-affirming the nineteenth century musical order led by France. Strikingly, the report of the Commission does not even refer to the Vienna conference but to the French decree of 1859, harkening back to the era of Napoleonic grandeur ${ }^{44}$ : "The Sub Committee for Arts and Letters concludes that the arrangements presented by the Committee in charge of establishing a uniform musical pitch during the 1858 Conference, are still fully valid today [...]. [It] expresses the wish to see all possible means taken by relevant authorities to maintain the 1858 standard." 45 The decision of the League of Nations, however, did not prevail and in the 1930s, the US confirmed their position through the voice of the American Bureau of Standards, which adopted $A 440$ as a reference pitch. This confirmation of the American position in sound negotiations was quickly followed by calls for the organization of new international conference on standard pitch.

The meeting confirmed what appears as the main trends in the American history of pitch standardization: the prevalence of commercial interests in other fields previously involved in the process - aesthetic and scientific especially - and the replacement of states in the negotiations by organizations in charge of regulating industrial exchanges. It was organized by the International Federation of Standard Associations, an institution founded in 1926 in order to facilitate international cooperation for industrial standardization, following the creation of national agencies: the British Engineering Standards Committee created in 1901, the Normenausschuß der Deutschen Industrie founded in 1917, as well the French Commission Permanente de Standardisation created in 1918. In 1939, these were the institutions - or their more recent avatars-representing states. Besides them, two international organizations took part in the discussions: the International Broadcasting Union, an institution based in Geneva, created in 1925 by several national broadcasting companies ${ }^{46}$; and the International Consultative Committee on Telephony. All of them, except for the Italian State, had recommended the adoption of 440 hertz ahead of the conference. ${ }^{47}$

Revealing the weight of the musical industry in the debates, the meeting took place in the headquarters of the BBC and was solemnly opened by Sir Cecil Graves, the CEO of the company. ${ }^{48}$ Its importance is also visible when one looks more closely at the composition of some national delegations. For instance, besides two acousticians - one of them head of the acoustic section of the British Standard Agency - representatives from England included two instrument makers (piano and organ builders) and the Head Program Engineer of the BBC, then famous for having invented the iconic BBC ribbon microphone. ${ }^{49}$ The involvement of the broadcasting industry in the debates is understandable in the context of the 1930s as explained by acoustician and member of the British delegation Llewelyn S. Lloyd: "As soon as broadcasting entered into the field of discussion," he wrote, looking back at the London meeting, "a new background was automatically provided. It became impossible to cling to any purely insular views, for broadcasting afforded a ready means of comparing the pitches used in practice in different countries. ${ }^{, 50}$ The possibility to record sounds and hear back-toback performances of any orchestra in the technologized world marked an important shift in the history of standard pitch as it revealed more obviously than ever the lack of uniformity in musical practices. Moreover, the broadcasting industry also provided the musical world with 
a new means to enforce standardization. In 1935, the American Bureau of Standards started broadcasting $A 440$ on a WWV radio station, arguing that it "was free from the vagaries of the material objects," nature of the device that could convey a standard frequency to the ends of the world. The broadcasted signal offered the first "tuning device" that was simultaneously accessible by an international community of musicians. The American Bureau of Standards also suggested the use of A 440 pitches to telephone-ring tones, ${ }^{52}$ which would similarly create a uniform and global experience of technology for users of the Western world - a concern that explains the presence of a telephony committee at the 1939 London conference.

The broadcasting industry did not only weigh in the conversations held in London, it also deeply oriented the scientific experiments on which decisions of the delegations were based. In the documentation sent by the International Broadcasting Union, one finds evidence of new measurement procedures that represented a little revolution in the field of acoustics. Until then, scientific experiments on musical pitch consisted in the testing of musical instruments and tuning devices' initial frequencies, outside any kind of musical context. In 1938, the Union used recorded materials in order to measure the variations of pitch frequency over the course of concerts. The experiment led by the International Broadcasting Union actually followed a pioneering study led in Berlin in 1937 at the Physical and Technical Institute by Werner Lottermoser, who was the assistant of the head of the German delegation at the 1939 conference. This study is mentioned several times in the material sent by national delegations ahead of the London meeting. In the context of the American standardization of pitch and the following debates that arose in Europe, Lottermoser led an unprecedented research based on the frequency testing of hundreds of broadcasting recordings "in order to get a general view on the question of knowing whether the European orchestras hold the pitch $A 435$, as required by the international Vienna Standard Pitch Conference." ${ }^{, 3}$ By using this method, scientists could claim they were standing as close as possible to the reality of current musical practices although the tested corpus was clearly reflecting the classical music programs broadcasted on radios, opening to a tuning of the world essentially indexed on the symphonic canon promoted by stations around the Western world.

In interwar America and Europe, the tuning of the world was re-negotiated according to procedures that revealed two main reorganizations. Given the importance of the North American market in a globalized world of musical trade, the United States imposed themselves as a new leader in the concert of nations. But more importantly, the diplomacy of sound left the vestibules of embassies and state administrations to develop new channels of negotiation created in order to regulate industrial exchanges, as the broadcasting industry was providing for the first time a literal concert of nations to ordinary listeners. Under the lead of these new sound standardizers, the technological unification of the Western musical world appears as a strikingly successful operation compared to other attempts to create international musical relations. The history of pitch standardization therefore mitigates the idea of a failure in interwar musical diplomacies: yet most musical transnational enterprises did not succeed in overcoming the contradictions between internationalism and nationalism, countries agreed upon a norm that was to survive the second world conflict and remains until the present an uncontested standard - although mostly loosely enforced by performers across the world. In other words, the history of pitch standardization invites us to reconsider the history of sound diplomacy in interwar. Demonstrating a form of "practical" or "technocratic internationalism," 54 pitch standardizers successfully achieved a quite literal international concord, by pursuing profit and technological efficiency rather than cultural rapprochement and political ideals. 


\section{Epilogue-The "Sounds of war" 55}

The empowerment of international organizations representing the interests of the musical industry in pitch negotiations created conflict within individual countries. As ISO was organizing a new meeting to validate the decision of the 1939 conference, whose enforcement the war had delayed, in France, composer Robert Dussaut started an active campaign to denounce the 1939 decision. Suggesting that the chosen reference was "German" and defending the authority of French musical and scientific traditional institutions, he organized a referendum amongst French musicians, and tried to oppose the legality of granting standardizing agencies the power to decide on state reforms. In a 1951 letter to Head of the Paris Conservatory Claude Delvincourt, Dussaut wrote about AFNOR and ISO: "these organizations are not official. They are far from having the great prestige of the Academy of Sciences. [...] Physicists credit us, so do the musicians. They consider $A 440$ illegal., ${ }^{, 56}$ Responding to his call, in August 1951, the French state appointed a new diapason commission formed by members of the Academy of Fine Arts, the Conservatory and the Academy of Sciences; but also by performers, especially singers, and instrument builders - a very consensual gathering that nevertheless excluded one of the main agents of standardization at this point: the broadcasting industry. ${ }^{57}$ While ISO was cultivating the same technocratic internationalism that began before the war, the government was reviving a diplomacy of sound typical of 1850s. The experts from the state-appointed committee were dreaming of a natural, scientific and "true" standard advertised by Italy in Vienna- $A 432$.

If debates about the diapason pitch were still alive in the $1970 \mathrm{~s},{ }^{58}$ when ISO issued the latest version of the diapason norm, called ISO 16, they now seem to be over-at least in the places where dissidents were previously most active, such as circles of classical music performance in France. ${ }^{59}$ Standard pitch, as a matter of diplomacy, is firmly in the hands of international organizations representing the interests of the musical industry. But doubts about A 440 persist in new places. Drawing on Dussaut and his supporters' strategic suggestions about the "German" character of the London standard ${ }^{60}$ and following a campaign launched by political activist and pamphlet-writer Lyndon LaRouche at the end of the 1980s in favor of what he called "Verdi's pitch," 61 a number of conspiracy theories have circulated denouncing the adoption of what they consider a Nazi norm, pointing out the fact that Goebbels was propaganda director by the time of the 1939 meeting, and therefore in charge of the German Radio. If the history of standard pitch reveals the importance of the United States rather than Germany in imposing $A 440$ in interwar-although the frequency was originally German norm" at the time it was chosen by American musicians, it was definitely not Nazi-the development of acoustic knowledge in the twentieth century is still closely linked with political and military histories. This is especially true of the Physical Technical Institute in Berlin, where Lottermoser ran his experiments on radio in 1937. The Institute's acoustic lab was created in 1934 for military purposes in the context of the German rearmament and as a result of the Nazification of the scientific policy of the institution-where physicists were asked to abandon fundamental research in favor of practical experiments. ${ }^{62}$ During World War II, the use radio and other new technologies of sound to encrypt communications and locate enemies in the field created an explicit link between the acoustical knowledge that led to an internationalization of musical pitch and the increasingly nationalized research agendas for the development of technologies that would make the difference in the pitched battles of WWII. 
1 "Peut-être depuis qu'il existe de la Musique n'a-t-on concerté deux fois sur le même ton" (Jean-Jacques Rousseau, “Ton,” Dictionnaire de musique (Paris: V Ve Duchesne, 1768), p. 516).

${ }^{2}$ Bruce Haynes, A History of Performing Pitch: The Story of " $A$ " (Lanham, Mar., and Oxford: The Scarecrow Press, 2002). The study of Bruce Haynes partly relies on the work of British mathematician and philologist Alexander J. Ellis, who published a comprehensive and detailed history of the performing pitch as a contribution to contemporary debates related to pitch measure and regulation (it therefore needs to be read with precaution): "On the History of Musical Pitch," Journal of the Royal Society of Arts 28 (March, 5 and April, 2, 1880): 293336 and 400-403). These two articles have been republished in the following volume: Studies in the History of Musical Pitch: Monographs by Alexander J. Ellis and Arthur Mendel (Amsterdam: Frits Knuf, 1968), pp. 11-62.

${ }^{3}$ Myles W. Jackson, Harmonious Triads. Physicists, Musicians, and Instrument Makers in Nineteenth-Century Germany (Cambridge: Massachusetts Institute of Technology Press, 2006).

${ }^{4}$ By using Jessica Ginow-Hecht's book title (Sound Diplomacy: Music and Emotions in Trans Atlantic Relations) in a literal sense, I mean to open the conversation on music and diplomacy to the field of sound studies.

${ }^{5}$ Myles W. Jackson, Harmonious Triads, p. 199.

${ }^{6}$ The argument of a constant rise of the pitch has been dismissed by Émile Leipp and Michèle Castellengo, "Du diapason et de sa relativité," La Revue musicale 294 (1977): 7-10.

7 In 1840, for instance, music scholar and critic François-Joseph Fétis denounced the "murdering of singers" ("l'assassinat des chanteurs" ["Du changement de diapason que l'on dit projeté à l'Opéra," Revue et gazette musicale de Paris, January 23, 1840: 55).

${ }^{8}$ Emmanuel Hervé, "Le diapason de l'Opéra de Paris," Musique. Images. Instruments 12 (2010): 199-200.

${ }^{9}$ Hervé, "Le diapason de l'Opéra de Paris": 200-201.

${ }^{10}$ The commission comprised three employees of the Paris opera (Dubois, stage manager; Bonnemer, cashier; and Kreutzer, orchestra director), as well as three members of the Conservatory (Cherubini, director; Berton and Boieldieu, both professors), the superintendent of the Royal Chapel (Lesueur), the director of the Royal Chapel's Music (Päer) and the orchestra director of the Théâtre-Italien (Grasset) (Académie royale de musique, handwritten report by the June $21^{\text {st }} 1824$ Commission in $\left.\mathrm{AN}, \mathrm{AJ} / 13 / 114\right)$.

11 "Les membres de la commission [...] ont pensé que cette amélioration pourrait dans les premiers jours, surprendre le public en le désaccoutumant à des effets trop éclatants auxquels son oreille est habituée depuis plusieurs années; mais comme ils jugent la mesure extrêmement utile, dans la vue qu'elle s'introduise sans trop de choc, et qu'elle ne puisse souffrir de la comparaison avec le diapason présentement en usage, ils sont d'avis que l'on prie S. Exc. d'interposer ses bons services pour que le diapason de l'Académie Royale de Musique ainsi rétabli, devienne en même temps celui des Théâtres lyriques royaux, de l'École Royale, et de la Chapelle" [Ibid.]).

${ }^{12}$ For a short biography of Lissajous, see Serge Benoit, Daniel Blouin, Jean-Yves Dupont and Gérard Emptoz, "Chronique d'une invention : le phonautographe d'Édouard-Léon Scott de Martinville (1817-1879) et les cercles parisiens de la science et de la technique," Documents pour l'histoire des techniques 17(1) (2009): 89.

${ }^{13}$ Jules-Antoine Lissajous, "Note sur l'élévation progressive du diapason des orchestres depuis Louis XIV jusqu'à nos jours et sur la nécessité d'adopter un diapason normal et 
universel," Bulletin de la Société d'Encouragement pour l'Industrie Nationale 54(2) (1855): 293-297.

${ }^{14}$ On the Société d'Encouragement pour l'Industrie Nationale, see Serge Benoît, Gérard Emptoz and Denis Woronoff (eds), Encourager l'innovation en France et en Europe. Autour du bicentenaire de la Société d'Encouragement pour l'industrie nationale (Paris: CTHS, 2006). On the specific role of the Société for musical innovation, see Benoit, Blouin, Dupont and Emptoz, "Chronique d'une invention: le phonautographe."

${ }^{15}$ Lissajous, "Note sur l'élévation progressive du diapason": 294, n. 4.

16 "I reserve myself, when we will deal with this determination, to offer a new method, based on the drawing of vibrations by the diapason itself" ("Je me réserve, lorsqu'on s'occupera de cette détermination, de proposer une méthode nouvelle, fondée sur le tracé des vibrations par le diapason lui-même," Lissajous, "Note sur l'élévation progressive du diapason, p. 297, n. 3). One could also argue that Lissajous had commercial interests, as suggested by his denounciation of "cheap diapasons, made no-one knows where and attuned no-one knows how" ("diapasons de pacotille, fabriqués on ne sait où et réglés on ne sait comment") in his "Note", as well as by the strong advertisement made by Delezenne in favor of the present and future collaboration between Lissajous and instrument builder Lerebours, for the production of diapason forks tuned to the new étalon. See "Correspondance," Le Luth français, July 5, 1856: 5. It is still unclear yet to me though if this collaboration started before or after the 1855 meeting at the Société.

${ }^{17}$ The necessity to discuss collectively the issue of standard pitch might explain the early gathering of various instrument makers in the same union mentioned by Constant Pierre, Les facteurs d'instruments de musique. Les luthiers et la facture instrumentale. Précis historique (Paris: Sagot, 1893) but questioned by Malou Haine, Les Facteurs d'instruments de musique à Paris au XIX ${ }^{e}$ siècle: des artisans face à l'industrialisation (Brussels: Éditions de l’Université, 1985), p. 293.

${ }^{18}$ Arrêté du 17 juillet 1858, Ministère d'État, Rapports et arrêtés pour l'établissement en France d'un diapason normal (Paris: Librairie impériale, 1859, p. 3, AN, F/21/768).

${ }^{19}$ Arrêté du 17 juillet 1858 , p. 4.

${ }^{20}$ Arrêté du 17 juillet 1858 , p. 3.

21 “N'est-il pas désirable qu'un diapason uniforme et désormais invariable vienne ajouter à cette communauté intelligente un lien suprême et qu'un la, toujours le même, résonnant sur toute la surface du globe, avec les mêmes vibrations, facilite les relations et les rende plus harmonieuses encore?" (Arrêté du 17 juillet 1858, p. 12). This universalist ambition had already been expressed by Lissajous (see "Note sur l'élévation progressive du diapason," p. 297) and was shared by the Société des fabricants de pianos: "In the same way science, at the beginning of this century, fixed the standard for metric measures, based on invariable elements taken from nature, isn't it logical that the musical art finds in an instrument given by the laws of physics a sound standard with which everyone will want to conform and which will be transmitted from generation to generation?" ("[D]e même que la science, au commencement de ce siècle, a fixé l'étalon des mesures métriques, en prenant pour base des éléments invariables et puisés dans la nature même, n'est-il pas logique que l'art musical, à son tour, trouve dans un instrument donné par les lois de la physique un étalon sonore universel, auquel chacun voudra se conformer, et qui se transmettra d'âge en âge ?," Henri Hoche, "De l'unité du diapason," Le Luth français, June 5, 1856: 3).

22 Jackson, Harmonious Triads, p. 209.

${ }^{23}$ The term is used by Alexander J. Ellis to characterize the decision of the 1858 commission ("On the History of the Musical Pitch," p. 312). 
${ }^{24}$ Or rather 870 double vibrations, which is the way frequency was measured in France at the time.

${ }^{25}$ Ministère d'État, Rapports et arrêtés pour l'établissement en France d'un diapason normal, p. 33.

${ }^{26}$ Ken Alder, "A Revolution in Measure: The Political Economy of the Metric System in France," in M. Norton Wise, ed., The Values of Precision (Princeton: Princeton University Press, 1995), p. 52.

${ }^{27}$ See the correspondance between Jauniac, architect of the Conservatory and the ministry of Fine Arts held in AN, F/21/768.

${ }^{28}$ Arrêté du 31 mai 1859 (AN, AJ/37/81).

${ }^{29}$ The same phenomenon is attested in other countries after their adoption of the French pitch. Over the course of the 1860s, the French pitch was introduced in Boston, where the organ of the Music Hall was especially tuned according to this standard, but "[m]eanwhile the musical instruments in use in the various orchestras were still at the high pitch, and opera troupes and other foreign musical organizations employed the same standard. Serious difficulty was experienced when the Great Organ was used in connection with an orchestra. After a time, in fact, at two separate periods, the Harvard Symphony Orchestra was furnished with instruments in accord with the organ, but apart from the concerts of this society, at theaters and elsewhere, the performers were still obliged to use instruments at the high concert pitch, which naturally caused much annoyance," Charles R. Cross, "Historical Notes Relating to Musical Pitch in the United States," Proceedings of the American Academy of Arts of Sciences 35 (1900): 453-454.

${ }^{30}$ Bruce Haynes, A History of Performing Pitch, p. 352.

${ }^{31}$ On the history of musical pitch in nineteenth-century America, see Charles R. Cross, "Historical Notes Relating to Musical Pitch in the United States." By the time he writes, Cross considers that America is generally tuned to the French pitch.

${ }^{32}$ International Organization and Industrial Change. Global Governance since 1850 (Oxford and New York: Oxford University Press, 1994), p. 56. For a list of the topics covered by such conferences, see table 3, "European and world conferences, 1850-1914, pp. 57-59.

${ }^{33}$ Kaiserlich-Königliches Ministerium für Cultus und Unterricht (ed.), Beschlüsse und Protokolle der Internationalen Stimmton Conferenz in Wien 1885 (Vienna: KaiserlichKöniglicher Schulbücher, 1885 [Bundesarchiv, Berlin, from now on BA, R/901/70190]). German archival material used in this article has been collected thanks to the support of the Max Planck Institute for the History of Science in Berlin.

${ }^{34}$ The Austrian State followed the recommendation of the Gesellschaft für Musikfreunde that considered France as a leader in terms of pitch standardization, as expressed by the use of this revealing quote in the preparatory documentation sent ahead of the Vienna conference: "Let there be light!' It was the voice of France" ("Es werde Licht!' Es war die Stimme Frankreichs," Exposé zu der Eingabe der Gesellschaft der Musikfreunde und Genossen No 26 vom 22. Januar in Wien an das $k$. $k$. Cultus- und Unterrichtsministerium, betreffend die Herbeiführung einer einheitlichen musikalischen Normalstimmung [BA, 901/79190], p. 2).

${ }^{35}$ Charles Meerens, Le Diapason et la notation musicale simplifiée (Paris: Schott, 1873). An Italian version of this text was published in 1876: Il Diapason (Corista). Versione con l'aggiunta di alcune noie di Gioacchino Muzzi (Rome: G. Muzzi).

36 "Die Strahlen dieser Sonne [der Wissenschaft] durchwärmen und durchdringen alle Disciplinen menschlichen Wissen, auch jene der Kunst. [...] Statt des wissenschaftlich vorzuziehenden Diapasons jenen von 870 Schwingungen wählen, hieße eine Art Anachronismus begehen." (Beschlüsse und Protokolle der Internationalen Stimmton Conferenz in Wien 1885, p. 16). 
${ }^{37}$ On the relationship between the bureaucratic state, standards and commerce, see M. Norton Wise, The Values of precision, p. 222 and following.

${ }^{38}$ Charles R. Cross, "Historical Notes Relating to Musical Pitch in the United States": 453.

${ }^{39}$ Deagan' firm was created in 1880 in Saint-Louis under the name "J.C. Deagan Musical Bells Co." In 1891, he moved to San Francisco. The firm became J.C. Deagan \& Co. in 1895 and in 1897 he settled in Chicago.

40 "The various nations [he wrote] have not been able to agree on the question of a universal pitch [...]. Recognizing this unfortunate condition we have produced a new standard tone measure, the Dea-gan-ometer, the function of which is to provide an easily understood, easily accessible and irrefutable PITCH STANDARD for the musician to work from, thus eliminating all uncertainty and guesswork regarding pitch or tuning. When once used, he added, the Dea-gan-ometer will be found as indispensable to the musician as the thermometer is to the physician, the compass to the mariner or the rule or scale is to the artisan or merchant." (The Dea-Gan-Ometer. A New Instrument for easily Ascertaining and Standardizing any Desired Pitch on a Scientific Basis (Chicago, 1916).

41 "Why the German Pitch? A Musical Innovation of Importance to American Orchestras," The sun, February 13, 1919: 6.

${ }^{42}$ Jessica Gienow-Hecht, Sound Diplomacy: Music and Emotions in Transatlantic Relations, 1850-1920 (Chicago: University of Chicago Press, 2009), pp. 169-170.

${ }^{43}$ Responding to the solicitation of the Boston Peace Foundation, the subcommittee for Arts and Letters Section of the League of Nations' International Committee on Intellectual Cooperation (created in 1922) starts working on the issue of standard pitch in 1926. Studies will actually mostly be led by the Institute of Intellectual Cooperation (co-founded in 1921 by France's government and the League of Nations and based in Paris). Detailed archival material on this matter is held at the UNESCO. On the musical politics of the League of Nations, see Christiane Sibille, "La Musique à la société des nations," Relations internationales 155(3) (2013): 89-102 and "Harmony Must Dominate the World." Internationale Organisationen und Musik in der ersten Hälfte des 20. Jahrhunderts (Bern: Quaderni di Dodis, 6, 2016), pp. 125-161.

${ }^{44}$ Christiane Sibille, "Harmony Must Dominate the World," pp. 143-148.

45 "La Sous-Commission des Lettres et des Arts [...] conclut que les arrangements présentés par la Commission chargée d'établir un diapason musical uniforme, lors de la Conférence de 1858 , conservent aujourd'hui toute leur valeur [...]. La Sous-Commission exprime le vœu que toutes les mesures utiles au maintien intégral du diapason de 1858 soient prises par les autorités responsables." (Société des Nations. Commisssion internationale de Coopération intellectuelle. Rapport présenté par M. Destrée au nom de la Sous-Commission des Lettres et des Arts, 19 July 1928 [Paris, UNESCO, C. I. C. I. / L. A. / 16, p. 9]).

${ }^{46}$ Suzanne Lommers, Europe - On Air. Interwar Projects for Radio Broadcasting (Amsterdam: Amsterdam University Press, 2012).

${ }^{47}$ See preparatory material held in BA, 4901/2741.

${ }^{48}$ W. C. Kaye, "International Standard of Musical Pitch," Nature 3630 (1939): 905.

${ }^{49}$ Asa Briggs, The History of Broadcasting in the United Kingdom (Oxford and New York: Oxford University Press, 1995, vol. 2, "The Golden Age of Wireless," p. 92).

50 "International Standard Musical Pitch," Journal of the Royal Society of Arts, 98 (1949): 76.

51 "Standard Musical Pitch,” NBS Technical News Bulletin, August 1957: 120.

52 "Standard Musical Pitch."

53 Werner Lottermoser, "Die Messung der Tonhöhe des Stimmtones a' bei Rundfunkmusikdarbietungen," Akustische Zeitschrift 1 (1938): 60. 
${ }^{54}$ Johan Schot and Vincent Lagendijk, "Technocratic Internationalism in the Interwar Years: Building Europe on Motorways and Electricity Network," Journal of Modern European History 6(2) (2008): 196-218.

${ }^{55}$ I borrow this expression from Annegret Fauser, Sounds of War. Music in the United Sates during World War II (Oxford: Oxford University Press, 2013).

${ }^{56}$ Letter from Robert Dussaut to Claude Delvincourt, March 30, 1951 (AN, AJ/37/486). He underlines.

57 “Arrêté du 6 août 1951," AN, 20140260/16.

${ }^{58}$ See Michèle Castellengo and Émile Leipp, "Du diapason et de sa relativité."

${ }^{59}$ ISO archives documenting the regular consultation of countries (every five years) on the issue of standard musical pitch show a constant consensus since the publication of the 1975 norm (archives of the Deutsche Institut für Normen, Berlin).

60 "Le Congrès de Londres, en 1939, fait en cachette des musiciens, a été organisé précisément par la maison Couesnon, de connivence avec la Radio allemande (Letter from Robert Dussaut [to Claude Delvincourt], s. d. [1950], AN, AJ/37/486); "L'Institut international du son (I. I. S.) a l'honneur de vous inviter à bien vouloir venir participer à ses délibérations en vue d'une proposition pour la fixation d'un nouveau diapason français, étant donné que le diapason allemand actuellement en usage (à 440 périodes), trop élevé, soulève de nombreux mécontentements en France." (Institut international du son. Organisme de documentation, de coordination, de centralisation et de diffusion des recherches acoustiques, and $\mathrm{AN}, \mathrm{AJ} / 37 / 486)$.

${ }^{61}$ See Lyndon LaRouche, "Revive Verdi's tuning to bring back great music," Executive Intelligence Review 15(32) (1988): 24-34.

${ }^{62}$ See Ulrich Kern, Forschung und Präzisionsmessung. Die Physikalisch-Technische Reichsanstalt zwischen 1918 und 1948 (Weinheim and New York: VCH Verlagsgesellschaft, 1994); and Dieter Hoffmann, "Die Physikalisch-Technische Reichsanstalt im Dritten Reich," PTB Mitteilungen 122(2) (2012): 30-31. 